\title{
Substituted Molecular $p$-Dopants: A Theoretical Study
}

\author{
Asanga B. Padmaperuma \\ Applied Materials Sciences Group, Pacific Northwest National Laboratory, Richland, USA \\ Email: asanga.padmaperuma@pnl.gov
}

Received May 1, 2012; revised June 9, 2012; accepted July 17, 2012

\begin{abstract}
Conductivity dopants with processing properties suitable for industrial applications are of importance to the organic electronics field. However, the number of commercially available organic molecular dopants is limited. The electron acceptor 2,3,5,6-tetrafluoro-7,7,8,8,-tetracyanoquinodimethane (F4-TCNQ) is the most utilized p-dopant; however, it has high volatility and a poor sticking coefficient, which makes it difficult to control doping levels and prevent vacuum system contamination. A design concept for $p$-type molecular dopants based on the TCNQ core which are substituted to improve processing properties without sacrificing the electronic properties necessary is presented. The correlation between the lowest unoccupied molecular orbital (LUMO) energy and the position of substitution as well as the choice of linker is evaluated. The position of substitution as well as the choice of linker has a significant effect on the electronic properties. However, the geometry of the substituted molecules was not significantly distorted from that of the parent F4-TCNQ, and the electron density was delocalized on the TCNQ core. We also put forward four possible molecular dopants with suitable energy levels.
\end{abstract}

Keywords: OLED; Molecular Dopant; F4-TCNQ; Anchored Dopants

\section{Introduction}

Organic Light-Emitting devices (OLED) are currently used in commercial displays and high-end white lighting. For energy-saving concerns, high quantum efficiency of light emission with a low device operating voltage is required. Phosphorescent OLEDs have high quantum efficiency, but the device drive voltages still need improvement when resistive organic materials are used. This issue can be addressed by the use of conductivity doping of the charge transporting layers [1]. For example, $p-i-n$ OLED devices which consist of doped Hole Transporting (HTL) and Electron Transporting Layers (ETL) have shown good Ohmic contacts, small injection barriers and low operation voltages [2]. However, the number of $p$-type conductivity dopants compatible with holetransporting materials for organic electronics is limited. Organic molecular acceptor compounds like 2,3,5,6-tetrafluoro-7,7,8,8,-tetracyanoquinodimethane (F4-TCNQ) [2], and its derivative 2,2'-(2,5-dicyano-3,6-difluorocyclohexa-2,5-diene-1,4-diylidene)dimalononitrile (F2-HCNQ) [3] have been used as $p$-dopants in OLEDs. However, controlling doping concentrations [4], and molecular diffusion [5] remains a challenge because F4-TCNQ has a high volatility and low sticking coefficient posing significant vacuum system contamination issues. Adding substituent groups to F4-TCNQ is one method of improving the high volatility and low sticking coefficient.
The use of computational methods to investigate the geometric and electronic properties of a series of TCNQbased analogs is discussed in this paper. F4-TCNQ molecule can be substituted at two possible locations; a) the fluorine of the core ring or one of the b) peripheral cyano groups can be replaced with a bulky substituent as shown in Figure 1. A bulky adamantane moiety is used as the inert group that can be attached to the core-F4-TCNQ moiety by several linkers. The implication of the position of substitution and the type of linker group is discussed using theoretical methods.

\section{Theoretical Methods}

All calculations were performed with the NWChem computational package [6] at the Molecular Science Computing Facility (MSCF) in the Environmental Molecular<smiles>N#CC(C#N)=c1c(F)c(F)c(=C(C#N)C#N)c(F)c1F</smiles>

F4-TCNQ

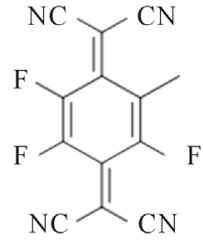

A<smiles>CC(C#N)=c1c(F)c(F)c(=C(C#N)C#N)c(F)c1F</smiles>

Figure 1. Chemical structures of the parent and the two model compounds used in the initial study. 
Sciences Laboratory (EMSL). Molecular orbitals and bond lengths were visualized using Extensible Computational Chemistry Environment (ECCE) a component of the Molecular Science Software Suite $\left(\mathrm{MS}^{3}\right)$ developed at the Pacific Northwest National Laboratory (PNNL). Geometry optimization and electronic properties were computed at the density functional theory (DFT) level. For the DFT calculations B3LYP hybrid functionals were employed [7]. For the geometry optimization Pople's standard split-valence plus polarization $6-31 \mathrm{G}^{*}$ basis set was used. In previous work, we studied F4-TCNQ using different DFT type functionals and $6-31 \mathrm{G}^{*}$ as the basis set. From this work we established the B3LYP/6-31G* level of theory gave values that closely matched the experimental values for bond lengths, bond angles and orbital energies [8,9]. The highest occupied molecular orbital (HOMO) and LUMO energies were determined from the minimized singlet geometry. Electron binding energies and ionization potentials of molecules are calculated by the delta self-consistent field $(\triangle \mathrm{SCF})$ as the difference in energy between a molecule and its radical cation. The same level of theory was applied to both the anion and the neutral species for the electron affinity calculations. The spin unrestricted B3LYP (UB3LYP) density functional was employed to treat the species with an ionized open-shell doublet (one unpaired electron) electron configurations. The results obtained with the SCF method were compared with calculations based on the traditional Koopmans' theorem approach [10]. The calculations of the electronic properties reported in this paper were carried out using cc-pVDz basis set [11].

\section{Results and Discussion}

For efficient $p$-doping of the hole transport material (HTM), the LUMO level of the dopant should be closely aligned with the HOMO level of the HTM as described in Figure 2. Commonly used hole transport molecules have HOMO level in the range of $4-5 \mathrm{eV}$, and the dopant must have a LUMO level deeper than $5 \mathrm{eV}$. Molecular acceptors such as, F4-TCNQ $[4,10]$ and its derivatives [11] have been used as p-dopants in OLEDs. The $E_{\text {LUMO }}$ of F4-TCNQ was estimated to be $5.24 \mathrm{eV}$ from inverse photoemission spectroscopy (IPES) measurements by Kahn et al. [12] From HOMO/LUMO alignment considerations, F4-TCNQ can accept electrons from a number of hole transport materials used in OLEDs. The substituent groups introduced to make the molecules more amenable for processing should not change the $E_{\text {LUMO }}$ of the dopant significantly.

\subsection{Effect of the Position of Substitution}

The parent molecule F4-TCNQ can be substituted at two positions; 1) an outer cyano group can be replaced, or 2)

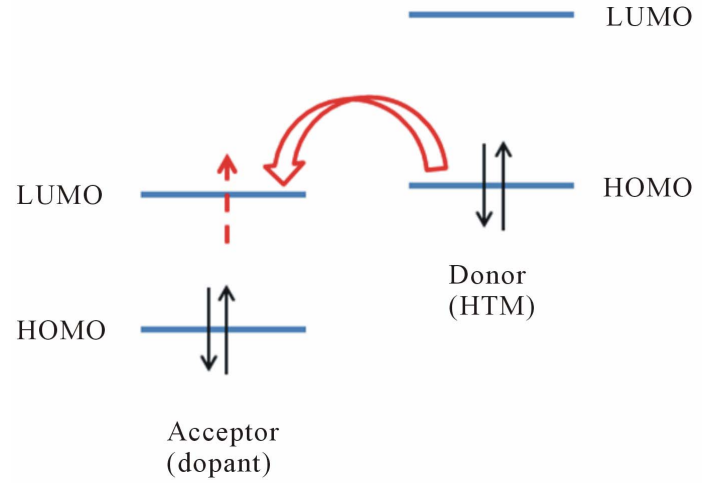

Figure 2. A schematic representation of energy level alignment required for efficient $p$-type doping.

a fluorine atom in the inner ring can be replaced (see Figure 1). The chemistry of the two options is different, and the position of choice will affect the electronic properties. To study the impact on electronic properties, two model compounds were studied: 2,2'-(2,3,5-trifluoro-6methylcyclohexa-2,5-diene-1,4-diylidene)dimalononitrile (F3-TCNQ-a), and 2-(4-(1-cyanoethylidene)-2,3,5,6-tetrafluorocyclohexa-2,5-dien-1-ylidene)malononitrile (F4TCNQ-b). The chemical structures for these two model compounds are shown in Figure 1.

TCNQ was studied in detail by Milián et al. using several methods and basis sets [12]. The predicted geometry of the molecules was insensitive to the method or the basis set employed. Due to similarities between TCNQ and F4-TCNQ, the geometry optimization of the latter was carried out at B3LYP/6-31G* level of theory. The calculated geometrical parameters compared well with the available experimental data. As a result for this study B3LYP/6-31G* level of theory was used to obtain the optimized geometry for unknown molecules. The predicted bond lengths and bond angles for F3-TCNQ-a, F4-TCNQ-b and F4-TCNQ are given in Supplementary information (Tables S1 and S2). No distortions in the TCNQ core were seen upon methyl substitution. From these model studies we can assume that proposed substitutions to the TCNQ core to improve physical properties will not affect the planar geometry of the core of the dopant.

Theoretically predicted $E_{\mathrm{LUMO}}$ and the adiabatic electron affinity (AEA) calculated form the optimized geometry using the using cc-pVDz basis set are shown in Table 1. Substitution of the core destabilizes the LUMO level of the parent molecule. Replacing a fluorine atom with a $-\mathrm{CH}_{3}$ group destabilizes the LUMO by $0.22 \mathrm{eV}$, whereas substitution of a cyano groups causes the LUMO to destabilize by $0.78 \mathrm{eV}$. A similar result was also seen for the AEA, where the replacement of the cyano groups caused the electron affinity to reduce by $0.78 \mathrm{eV}$. These data imply that substitution should not be 
Table 1. The energies of the LUMO state and Electron Affinities (EA) of the model compounds studied and the parent compound F4-TCNQ.

\begin{tabular}{ccc}
\hline & $E_{\text {LUмо }}(\mathrm{eV})$ & AEA $(\mathrm{eV})$ \\
\hline F4-TCNQ & -5.32 & 3.75 \\
F3-TCNQ-a & -5.10 & 3.55 \\
F4-TCNQ-b & -4.54 & 2.97 \\
\hline
\end{tabular}

done at the cyano groups. Although the LUMO level was slightly destabilized, substitution of the fluorine atoms seems to be a better option to design dopants. The electron density plots for both HOMO and LUMO levels for this series of molecules are shown in Figure 3. The figure shows that the electron densities of molecule did not change significantly upon substitution. We can assume from the data that substitution of the TCNQ core should not affect the orbital overlap between the dopant molecule and potential HTMs that is essential for electron transfer.

\subsection{Effect of the Linker Group}

For this work we studied four linking moieties as shown in Figure 4. In two of the choices the TCNQ core is attached to the anchor via a $-\mathrm{CH}_{2}$ - group and other two anchors are attached via a $-\mathrm{OCH}_{2}$ - based linker. Additional way to increase the thermal stability is to include a phenyl group in the anchor. Since the phenyl group is not directly attached to the TCNQ core, it will have limited effect on the electronic properties but there still could be a steric effect. The geometry optimization of the second series of dopants was carried out at B3LYP/6-31G* level of theory. Bond lengths obtained from the optimized geometries are shown in Supplementary information. Of the bonds that represent the TCNQ core only $\mathrm{C}_{2}-\mathrm{C}_{3}(\Delta \%$ $=$ between $0.9 \%$ and $1.45 \%)$, and $\mathrm{C}_{1}-\mathrm{F}_{18}(\Delta \%=$ between $0.4 \%$ and $0.94 \%$ ) bonds showed significant change from F4-TCNQ upon substitution.

The change in bond angles upon substitution was studied using the optimized geometries, and these values are shown in Table 2. The complete list of predicted bond lengths and bond angles for the molecules in this series is given in Supplementary information (Table S3 through Table S12) [13]. The change caused by replacing a fluorine moiety in the core with the linker was minimal $(\Delta \%<0.8 \%)$ for majority of the bond angles. On average, the bulky - $\mathrm{CH}_{2}$ - groups had a larger effect than the -O- moiety. The oxygen substitution had the largest effected on the $\mathrm{R}_{1}-\mathrm{C}_{2}-\mathrm{C}_{1}$ bond angle. For F3TCNQ 3 and F3-TCNQ 4 the bong angle increased by $4.48^{\circ}$ and $4.59^{\circ}$ respectively upon substitution. For the $-\mathrm{CH}_{2}$ - substituted dopants, F3-TCNQ 1 and F3-TCNQ
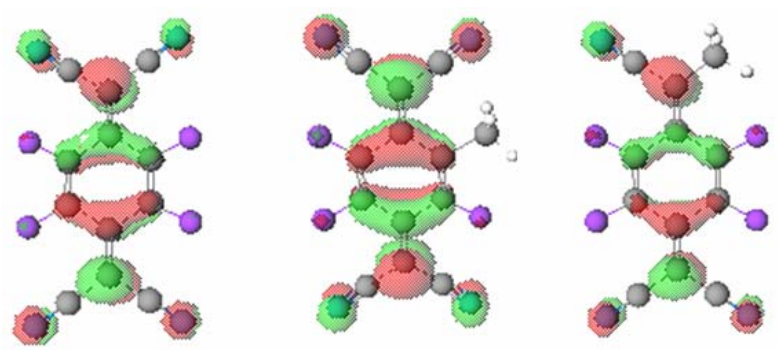

(a)

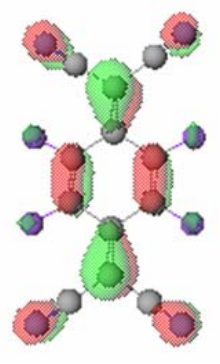

F4-TCNQ

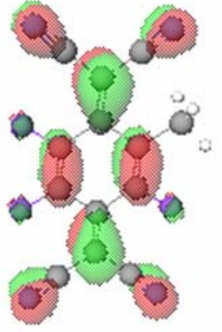

F3-TCNQ-a

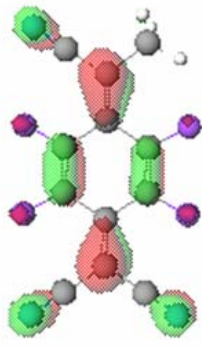

F4-TCNQ-b (b)

Figure 3. Electron density maps for the two model compounds and F4-TCNQ; (a) LUMO level; (b) HOMO level.

2 the $\mathrm{R}_{1}-\mathrm{C}_{2}-\mathrm{C}_{1}$ bond angle reduced by $1.67^{\circ}$ and $1.00^{\circ}$ respectively. Bond angles around the $\mathrm{C}_{2}$ position had the largest effect upon - $\mathrm{CH}_{2}$ - substitution. The $\mathrm{R}_{1}-\mathrm{C}_{2}-\mathrm{C}_{1}$ angle was increased by $6.59^{\circ}$ for F3-TCNQ 1 and by $5.82^{\circ}$ for F3-TCNQ 2. In all cases significant distortions were not seen in dopants that had a phenyl ring as a part of the anchor. Similar trends were seen in dihedral angles for these molecules as well. (See Supplementary information). As expected, substitution of a fluorine atom from the TCNQ core causes the bond angles to change, but the effects are not large enough to cause significant disrupttion of the $\pi$-system.

The change in bond angles upon substitution was studied using the optimized geometries, and these values are shown in Table 2 [13]. The change caused by replacing a fluorine moiety in the core with the linker was minimal $(\Delta \%<0.8 \%)$ for majority of the bond angles. On average, the bulky $-\mathrm{CH}_{2}$ - groups had a larger effect than the -Omoiety. The oxygen substitution had the largest effected on the $\mathrm{R}_{1}-\mathrm{C}_{2}-\mathrm{C}_{1}$ bond angle. For F3-TCNQ 3 and F3-TCNQ 4 the bong angle increased by $4.48^{\circ}$ and $4.59^{\circ}$ respectively upon substitution. For the $-\mathrm{CH}_{2}$ - substituted dopants, F3-TCNQ 1 and F3-TCNQ 2 the $\mathrm{R}_{1}-\mathrm{C}_{2}-\mathrm{C}_{1}$ bond angle reduced by $1.67^{\circ}$ and $1.00^{\circ}$ respectively. Bond angles around the $\mathrm{C}_{2}$ position had the largest effect upon $-\mathrm{CH}_{2}$ - substitution. The $\mathrm{R}_{1}-\mathrm{C}_{2}-\mathrm{C}_{1}$ angle was increased by $6.59^{\circ}$ for F3-TCNQ 1 and by $5.82^{\circ}$ for F3-TCNQ 2. In all cases significant distortions were not seen in dopants that had a phenyl ring as a part of the anchor. Similar trends were seen in dihedral angles for 


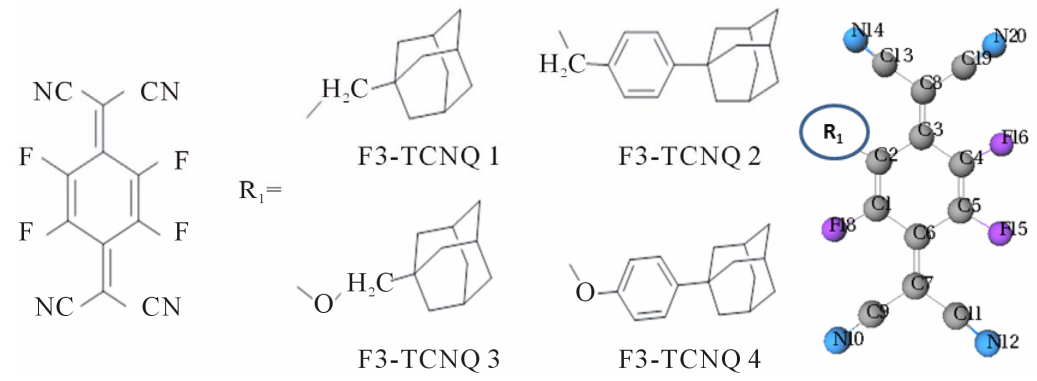

Figure 4. Chemical structures of the substituted F3-TCNQ derivatives studied, and the TCNQ core with atom numbers.

Table 2. Predicted bond angles.

\begin{tabular}{|c|c|c|c|c|c|}
\hline angles & F4-TCNQ & F3-TCNQ 1 & F3-TCNQ 2 & F3-TCNQ 3 & F3-TCNQ 4 \\
\hline R1 & $-F$ & $-\mathrm{CH}_{2-}$ & $-\mathrm{CH}_{2-}$ & $-\mathrm{O}-$ & $-\mathrm{O}-$ \\
\hline $\mathrm{C}_{1}-\mathrm{C}_{2}-\mathrm{C}_{3}$ & 122.74 & 117.82 & 117.78 & 119.59 & 120.46 \\
\hline $\mathrm{C}_{2}-\mathrm{C}_{3}-\mathrm{C}_{4}$ & 114.53 & 116.15 & 116.10 & 116.09 & 115.58 \\
\hline $\mathrm{C}_{3}-\mathrm{C}_{4}-\mathrm{C}_{5}$ & 122.74 & 123.48 & 123.43 & 122.65 & 122.77 \\
\hline $\mathrm{C}_{4}-\mathrm{C}_{5}-\mathrm{C}_{6}$ & 122.74 & 121.97 & 121.96 & 122.38 & 122.49 \\
\hline $\mathrm{C}_{1}-\mathrm{C}_{6}-\mathrm{C}_{5}$ & 114.53 & 113.69 & 113.74 & 114.56 & 114.57 \\
\hline $\mathrm{C}_{2}-\mathrm{C}_{3}-\mathrm{C}_{8}$ & 122.73 & 125.13 & 125.32 & 122.12 & 122.53 \\
\hline $\mathrm{C}_{4}-\mathrm{C}_{3}-\mathrm{C}_{8}$ & 122.74 & 118.72 & 118.56 & 121.77 & 121.89 \\
\hline $\mathrm{C}_{1}-\mathrm{C}_{6}-\mathrm{C}_{7}$ & 122.74 & 123.53 & 123.50 & 123.09 & 123.00 \\
\hline $\mathrm{C}_{5}-\mathrm{C}_{6}-\mathrm{C}_{7}$ & 122.74 & 122.78 & 122.76 & 122.34 & 122.41 \\
\hline $\mathrm{C}_{6}-\mathrm{C}_{7}-\mathrm{C}_{9}$ & 123.73 & 124.19 & 124.28 & 123.82 & 123.84 \\
\hline $\mathrm{C}_{6}-\mathrm{C}_{7}-\mathrm{C}_{11}$ & 123.73 & 123.54 & 123.51 & 123.81 & 123.76 \\
\hline $\mathrm{C}_{9}-\mathrm{C}_{7}-\mathrm{C}_{11}$ & 112.55 & 112.27 & 112.21 & 112.37 & 112.40 \\
\hline $\mathrm{C}_{3}-\mathrm{C}_{8}-\mathrm{C}_{13}$ & 123.74 & 125.51 & 125.57 & 124.37 & 124.79 \\
\hline $\mathrm{C}_{3}-\mathrm{C}_{8}-\mathrm{C}_{19}$ & 123.72 & 124.68 & 124.67 & 123.96 & 123.70 \\
\hline $\mathrm{C}_{13}-\mathrm{C}_{8}-\mathrm{C}_{19}$ & 112.54 & 109.79 & 109.71 & 111.63 & 111.52 \\
\hline $\mathrm{R}_{1}-\mathrm{C}_{2}-\mathrm{C}_{3}$ & 118.83 & 125.42 & 124.65 & 117.29 & 116.27 \\
\hline $\mathrm{R}_{1}-\mathrm{C}_{2}-\mathrm{C}_{1}$ & 118.43 & 116.76 & 117.43 & 122.91 & 123.02 \\
\hline $\mathrm{F}_{18}-\mathrm{C}_{1}-\mathrm{C}_{2}$ & 118.43 & 117.98 & 118.50 & 118.22 & 118.32 \\
\hline $\mathrm{F}_{18}-\mathrm{C}_{1}-\mathrm{C}_{6}$ & 118.83 & 115.22 & 114.70 & 117.18 & 117.60 \\
\hline $\mathrm{F}_{15}-\mathrm{C}_{5}-\mathrm{C}_{6}$ & 118.83 & 119.35 & 119.37 & 119.05 & 119.01 \\
\hline $\mathrm{F}_{15}-\mathrm{C}_{5}-\mathrm{C}_{4}$ & 118.43 & 118.67 & 118.66 & 118.58 & 118.49 \\
\hline $\mathrm{F}_{16}-\mathrm{C}_{4}-\mathrm{C}_{5}$ & 118.43 & 117.20 & 117.16 & 118.21 & 118.17 \\
\hline $\mathrm{F}_{16}-\mathrm{C}_{4}-\mathrm{C}_{3}$ & 118.83 & 119.31 & 119.34 & 119.12 & 119.06 \\
\hline
\end{tabular}

these molecules as well. (See Supplementary information.) As expected, substitution of a fluorine atom from the TCNQ core causes the bond angles to change, but the effects are not large enough to cause significant disruption of the $\pi$-system.
The lowest energy unoccupied molecular orbitals for these molecules are of importance for $p$-type dopants. For a suitable dopant, the $\pi$-orbital density of the LUMO state should be localized to the TCNQ core. This will enable proper electron density overlap with the hole 
transport (HT) molecules. The electron density plots for the four substituted dopants are depicted in Figure 5.

It was assumed that slight distortions resulted due to substitutions will not disrupted the electron density in these molecules. The data shown here prove that is the case, the electron localization of the LUMO state for these molecules are very similar to that of F4-TCNQ (Figure 3(a)). As such the substituted dopants should have the similar electron overlap with HT molecules as the parent F4-TCNQ.

Theoretically predicted $E_{\text {LUMO }}$ and the adiabatic electron affinity (AEA) calculated for the optimized geometry using the using cc-pVDz basis set for the substituted dopants are shown in Table 3.

As expected, the replacement of a fluorine atom with a $-\mathrm{CH}_{2}$ - or an -O- moiety destabilized the LUMO state. A molecule very similar to F3-TCNQ 1 was synthesized and studied. The predicted LUMO state of molecule F3ad1 was destabilized by $0.3 \mathrm{eV}$ compared to F4-TCNQ [14]. F3-adl was successfully used as a molecular pdopant for light emitting devices and thin film transistors [15]. From this information it is clear that all four candidates studied here have the appropriate energy levels to be used as molecular $p$-dopants.

\section{Conclusion}

Rational design for anchored molecular dopants based on the TCNQ core is described. The study aimed at improving the processing properties of molecular dopants without sacrificing the electronic properties. The theoretical geometry optimization was carried out using the B3LYP/ 6 - $31 \mathrm{~g}^{*}$ level, and the electronic properties were computed using the B3LYP/zz-pVDZ level of theory. The

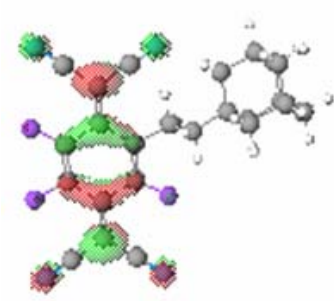

F3-TCNQ 1

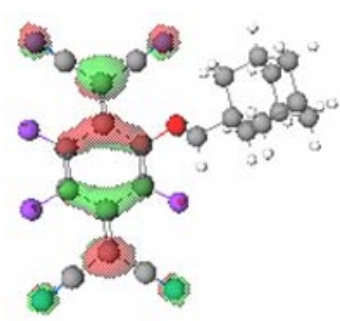

F3-TCNQ 3

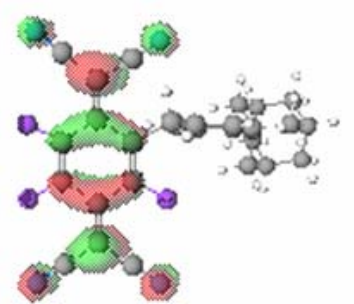

F3-TCNQ 2

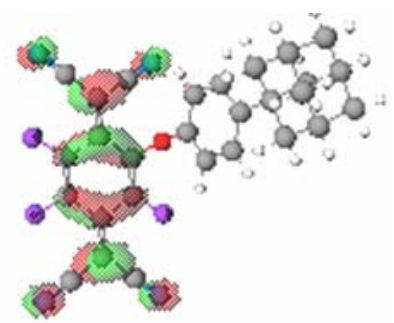

F3-TCNQ 4
Figure 5. Electron density of the LUMO state of the substituted molecules.
Table 3. The energies of the LUMO state and electron affinities (EA) of substituted TCNQs under study and the parent compound F4-TCNQ.

\begin{tabular}{ccc}
\hline & $E_{\text {LUmo }}(\mathrm{eV})$ & AEA $(\mathrm{eV})$ \\
\hline F4-TCNQ & -5.25 & 3.75 \\
F3-TCNQ 1 & -5.04 & 3.55 \\
F3-TCNQ 2 & -5.03 & 3.57 \\
F3-TCNQ 3 & -4.98 & 3.49 \\
F3-TCNQ 4 & -4.97 & 3.52 \\
\hline
\end{tabular}

preferred position of substitution was evaluated, and the replacement of the fluorine atom proved to be better than replacing the cyano groups. The effect of the linker was studied next, and it was proposed that based on theory both types of linkers studied would give rise to dopant with improved processing properties.

\section{Acknowledgements}

This work was funded by the Solid Sate Lighting Program of the US Dept. of Energy, within the Building Technologies Program (BT), (Award Nos. M6743231 and M68004043) and managed by the National Energy Technology Laboratory (NETL). A portion of this research was performed using Environmental Molecular Sciences Laboratory (EMSL), which is a national scientific user facility sponsored by the Department of Energy's Office of Biological and Environmental Research and is located at Pacific Northwest National Laboratory (PNNL). Computations were carried out using "NWChem, A Computational Chemistry Package for Parallel Computers, Version 5.1" (2007), developed at the High Performance Computational Chemistry Group, Pacific Northwest National Laboratory. Extensible Computational Chemistry Environment (ECCE), A Problem Solving Environment for Computational Chemistry, Software Version 6.0" (2009), as developed and distributed by Pacific Northwest National Laboratory, and funded by the U.S. Department of Energy, was used to obtain some of these results. Pacific Northwest National Laboratory is operated by Battelle Memorial Institute for the U.S. Department of Energy (DOE) under Contract No. DEAC0676RLO 1830.

\section{REFERENCES}

[1] K. Walzer, B. Maennig, M. Pfeiffer and K. Leo, "Highly Efficient Organic Devices Based on Electrically Doped Transport Layers," Chemical Reviews, Vol. 107, No. 4, 2007, pp. 1233-1271. doi:10.1021/cr050156n

[2] X. Zhou, M. Pfeiffer, J. Blochwitz, A. Werner, A. Nollau, T. Fritz and K. Leo, "Very-Low-Operating-Voltage Or- 
ganic Light-Emitting Diodes Using a $p$-Doped Amorphous Hole Injection Layer," Applied Physics Letters, Vol. 78, No. 4, 2001, p. 410. doi:10.1063/1.1343849

[3] B. X. Mi, Z. Q. Gao, K. W. Cheah and C. H. Chen, "Organic Light-Emitting Diodes Using 3,6-Difluoro-2,5,7,7,8,8Hexacyanoquinodimethane as p-Type Dopant," Applied Physics Letters, Vol. 94, No. 7, 2009, Article ID: 073507. doi:10.1063/1.3073719

[4] W. Gao and A. Kahn, "Electronic Structure and Current Injection in Zinc Phthalocyanine Doped with Tetrafluorotetracyanoquinodimethane: Interface versus Bulk Effects," Organic Electronics, Vol. 3, No. 2, 2002, pp. 5363. doi:10.1016/S1566-1199(02)00033-2

[5] C. Williams, L. Sergey, J. Ferraris and A. A. Zakhidov, "Exciton-Dopant and Exciton-Charge Interactions in Electronically Doped OLEDs," Journal of Luminescence, Vol. 110, No. 4, 2004, pp. 396-406. doi:10.1016/j.jlumin.2004.08.038

[6] M. Valiev, E. J. Bylaska, N. Govind, K. Kowalski, T. P. Straatsma, H. J. J. van Dam, D. Wang, J. Nieplocha, E. Apra, T. L. Windus and W. A. de Jong, "NWChem: A Comprehensive and Scalable Open-Source Solution for Large Scale Molecular Simulations," Computer Physics Communications, Vol. 181, No. 9, 2010, pp. 1477-1489. doi:10.1016/j.cpc.2010.04.018

[7] A. D. Becke, "Density-Functional Thermochemistry. III. The Role of Exact Exchange," The Journal of Chemical Physics, Vol. 98, No. 7, 1993, p. 5648. doi: $10.1063 / 1.464913$

[8] P. K. Koech, L. S. Sapochak, J. E. Rainbolt, L. Cosimbescu, E. Polikarpov, J. S. Swensen, L. Wang, A. B. Padmaperuma and D. J. Gaspar, "Design of New Anchored p-Dopants for High Power Efficiency OLEDs," Organic Light Emitting Materials and Devices XIII, Vol. 7415, 2009, Article ID: 741505. doi:10.1117/12.827298

[9] L. Cosimbescu, A. B. Padmaperuma and D. J. Gaspar, “7,7,8,8-Tetracyanoquinodimethane-Based Molecular Dopants for $p$-Type Doping of OLEDs: A Theoretical Investigation," The Journal of Physical Chemistry A, Vol. 115, No. 46, 2011, Article ID: 13498. doi:10.1021/jp2005869
[10] T. Koopmans, "Über die Zuordnung von Wellenfunktionen und Eigenwerten zu den Einzelnen Elektronen Eines Atoms," Physica, Vol. 1, No. 1-6, 1933, pp. 104113. doi:10.1016/S0031-8914(34)90011-2

[11] R. A. Kendall, T. H. Dunning and R. J. Harrison, "Electron Affinities of the First-Row Atoms Revisited. Systematic Basis Sets and Wave Functions," Journal of Chemical Physics, Vol. 96, 1992, p. 6796. doi:10.1063/1.462569

[12] B. Milián, R. Pou-Ame'rigo, R. Viruela and E. Orti, “A Theoretical Study of Neutral and Reduced Tetracyano- $p$ quinodimethane (TCNQ)," Journal of Molecular Structure: Theochem, Vol. 709, No. 1-3, 2004, pp. 97-102. doi:10.1016/j.theochem.2003.09.011

[13] A Complete Description of Bond Lengths, Bond Angles, and Dihedral Angles for Optimized Structures Are Provided in Supporting Information.

[14] J. E. Rainbolt, P. K. Koech, J. S. Swensen, E. Polikarpov, A. Von Ruden, L. Wang, L. Cosimbescu, L. S. Sapochak, A. B. Padmaperuma and D. J. Gaspar, "Synthesis and Characterization of $p$-Type Conductivity Dopant 2-(3(adamantan-1-yl)propyl)-3,5,6-trifluoro-7,7,8,8-tetracyanoquinodimethane," Journal of Materials Chemistry, 2012, in press.

[15] J. S. Swensen, L. Wang, J. E. Rainbolt, P. K. Koech, E. Polikarpov, A. B. Padmaperuma and D. J. Gaspar, "Characterization of Solution Processed, $p$-Doped Films Using Hole-Only Devices and Organic Field-Effect Transistors," Organic Electronics, 2012, in press. doi:10.1016/j.orgel.2012.07.045

[16] G. Black, J. Daily, B. Didier, T. Elsethagen, D. Feller, D. Gracio, M. Hackler, S. Havre, D. Jones, E. Jurrus, T. Keller, C. Lansing, S. Matsumoto, B. Palmer, M. Peterson, K. Schuchardt, E. Stephan, L. Sun, K. Swanson, H. Taylor, G. Thomas, E. Vorpagel, T. Windus and C. Winters, "ECCE, a Problem Solving Environment for Computational Chemistry, Software Version 4.5.1," Pacific NorthWest National Laboratory, Richland, 2007. 


\section{Supporting Information Available}

The SI includes the geometry parameters for the molecules studied.

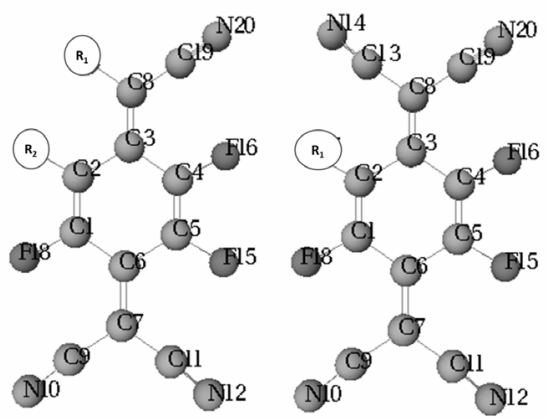

Figure S1. The atom numbers for the 2 classes of molecules studied, the computation were visualized using ecce [16].

Table S1. Predicted bond lengths for the model compounds and that for F4-TCNQ.

\begin{tabular}{|c|c|c|c|}
\hline Bond & F4TCNQ & F3TCNQ-a & F4TCNQ-b \\
\hline $\mathrm{R} 1$ & $\mathrm{CN}$ & $\mathrm{CN}$ & $\mathrm{CH}_{3}$ \\
\hline $\mathrm{R} 2$ & $\mathrm{~F}$ & $\mathrm{CH}_{3}$ & $\mathrm{~F}$ \\
\hline $\mathrm{C}_{8}-\mathrm{R}_{1}$ & 1.42917 & 1.42967 & 1.51292 \\
\hline $\mathrm{C}_{2}-\mathrm{R}_{2}$ & 1.33908 & 1.50828 & 1.33946 \\
\hline $\mathrm{C}_{1}-\mathrm{C}_{2}$ & 1.35908 & 1.36370 & 1.35830 \\
\hline $\mathrm{C}_{1}-\mathrm{C}_{6}$ & 1.44563 & 1.44936 & 1.44426 \\
\hline $\mathrm{C}_{2}-\mathrm{C}_{3}$ & 1.44563 & 1.46433 & 1.45290 \\
\hline $\mathrm{C}_{3}-\mathrm{C}_{8}$ & 1.38831 & 1.39246 & 1.38165 \\
\hline $\mathrm{C}_{8}-\mathrm{C}_{19}$ & 1.42921 & 1.43208 & 1.43067 \\
\hline $\mathrm{C}_{3}-\mathrm{C}_{4}$ & 1.44562 & 1.44880 & 1.45543 \\
\hline $\mathrm{C}_{4}-\mathrm{C}_{5}$ & 1.35909 & 1.35671 & 1.35736 \\
\hline $\mathrm{C}_{5}-\mathrm{C}_{6}$ & 1.44562 & 1.43875 & 1.44310 \\
\hline $\mathrm{C}_{6}-\mathrm{C}_{7}$ & 1.38839 & 1.38830 & 1.38817 \\
\hline $\mathrm{C}_{7}-\mathrm{C}_{9}$ & 1.42926 & 1.42691 & 1.42969 \\
\hline $\mathrm{C}_{7}-\mathrm{C}_{11}$ & 1.42926 & 1.43013 & 1.42967 \\
\hline $\mathrm{C}_{9}-\mathrm{N}_{10}$ & 1.16424 & 1.16428 & 1.16422 \\
\hline $\mathrm{C}_{11}-\mathrm{N}_{12}$ & 1.16424 & 1.16422 & 1.16420 \\
\hline $\mathrm{C}_{19}-\mathrm{N}_{20}$ & 1.16409 & 1.16429 & 1.16506 \\
\hline $\mathrm{C}_{1}-\mathrm{F}_{18}$ & 1.33103 & 1.34082 & 1.33467 \\
\hline $\mathrm{C}_{4}-\mathrm{F}_{16}$ & 1.33096 & 1.33325 & 1.33304 \\
\hline $\mathrm{C}_{5}-\mathrm{F}_{15}$ & 1.33102 & 1.33167 & 1.33467 \\
\hline
\end{tabular}

Table S2. Predicted bond angles for the model compounds and that for F4-TCNQ.

\begin{tabular}{cccc}
\hline angles & F4TCNQ & F3TCNQ-a & F4TCNQ-b \\
\hline $\mathrm{R} 1$ & $\mathrm{CN}$ & $\mathrm{CN}$ & $\mathrm{CH}_{3}$ \\
$\mathrm{R} 2$ & $\mathrm{~F}$ & $\mathrm{CH}_{3}$ & $\mathrm{~F}$ \\
$\mathrm{R}_{1}-\mathrm{C}_{8}-\mathrm{C}_{3}$ & 123.74 & 125.10 & 127.64 \\
$\mathrm{R}_{1}-\mathrm{C}_{8}-\mathrm{C}_{19}$ & 112.54 & 110.27 & 110.85 \\
$\mathrm{R}_{2}-\mathrm{C}_{2}-\mathrm{C}_{3}$ & 118.83 & 123.38 & 120.11 \\
$\mathrm{R}_{2}-\mathrm{C}_{2}-\mathrm{C}_{1}$ & 118.43 & 118.46 & 116.48 \\
$\mathrm{C}_{2}-\mathrm{C}_{3}-\mathrm{C}_{4}$ & 114.53 & 116.32 & 112.70 \\
$\mathrm{C}_{1}-\mathrm{C}_{6}-\mathrm{C}_{5}$ & 114.53 & 113.94 & 113.86 \\
$\mathrm{C}_{1}-\mathrm{C}_{6}-\mathrm{C}_{7}$ & 122.74 & 123.38 & 122.99 \\
$\mathrm{C}_{9}-\mathrm{C}_{7}-\mathrm{C}_{11}$ & 112.55 & 112.16 & 112.65 \\
$\mathrm{C}_{1}-\mathrm{C}_{2}-\mathrm{C}_{3}$ & 122.74 & 118.16 & 123.41 \\
$\mathrm{C}_{4}-\mathrm{C}_{5}-\mathrm{C}_{6}$ & 122.74 & 122.04 & 122.90 \\
$\mathrm{C}_{3}-\mathrm{C}_{4}-\mathrm{C}_{5}$ & 122.74 & 123.27 & 123.83 \\
\hline
\end{tabular}

Table S3. Predicted bond lengths for the substituted F3TCNQ derivatives and that for F4-TCNQ.

\begin{tabular}{cccccc}
\hline Bond & F4-TCNQ & F3-TCNQ1 & F3-TCNQ2 & F3-TCNQ3 & F3-TCNQ4 \\
\hline $\mathrm{R}_{1}$ & $-\mathrm{F}$ & $-\mathrm{CH}_{2}-$ & $-\mathrm{CH}_{2}-$ & $-\mathrm{O}-$ & $-\mathrm{O}-$ \\
$\mathrm{C}_{2}-\mathrm{R}_{1}$ & 1.33908 & 1.51586 & 1.52103 & 1.34110 & 1.34772 \\
$\mathrm{C}_{1}-\mathrm{C}_{2}$ & 1.35908 & 1.36498 & 1.36393 & 1.36851 & 1.36804 \\
$\mathrm{C}_{1}-\mathrm{C}_{6}$ & 1.44563 & 1.44684 & 1.44869 & 1.44173 & 1.44163 \\
$\mathrm{C}_{2}-\mathrm{C}_{3}$ & 1.44563 & 1.46458 & 1.46666 & 1.46265 & 1.45874 \\
$\mathrm{C}_{3}-\mathrm{C}_{8}$ & 1.38831 & 1.39320 & 1.39273 & 1.38758 & 1.38816 \\
$\mathrm{C}_{8}-\mathrm{C}_{19}$ & 1.42921 & 1.43240 & 1.43264 & 1.43061 & 1.43093 \\
$\mathrm{C}_{3}-\mathrm{C}_{4}$ & 1.44562 & 1.45103 & 1.45065 & 1.44450 & 1.44478 \\
$\mathrm{C}_{4}-\mathrm{C}_{5}$ & 1.35909 & 1.35629 & 1.35640 & 1.35708 & 1.35736 \\
$\mathrm{C}_{5}-\mathrm{C}_{6}$ & 1.44562 & 1.43862 & 1.43777 & 1.44532 & 1.44511 \\
$\mathrm{C}_{6}-\mathrm{C}_{7}$ & 1.38839 & 1.38859 & 1.38835 & 1.39021 & 1.39059 \\
$\mathrm{C}_{7}-\mathrm{C}_{9}$ & 1.42926 & 1.42945 & 1.42955 & 1.42932 & 1.42912 \\
$\mathrm{C}_{7}-\mathrm{C}_{11}$ & 1.42926 & 1.42988 & 1.43009 & 1.42919 & 1.42908 \\
$\mathrm{C}_{9}-\mathrm{N}_{10}$ & 1.16424 & 1.16426 & 1.16424 & 1.16431 & 1.16440 \\
$\mathrm{C}_{11}-\mathrm{N}_{12}$ & 1.16424 & 1.16416 & 1.16414 & 1.16430 & 1.16438 \\
$\mathrm{C}_{19}-\mathrm{N}_{20}$ & 1.16409 & 1.16443 & 1.16441 & 1.16419 & 1.16411 \\
$\mathrm{C}_{13}-\mathrm{N}_{14}$ & 1.16409 & 1.16489 & 1.16479 & 1.16485 & 1.16466 \\
$\mathrm{C}_{1}-\mathrm{F}_{18}$ & 1.33103 & 1.34213 & 1.34357 & 1.34154 & 1.33636 \\
$\mathrm{C}_{4}-\mathrm{F}_{16}$ & 1.33096 & 1.33374 & 1.33342 & 1.33320 & 1.33238 \\
$\mathrm{C}_{5}-\mathrm{F}_{15}$ & 1.33102 & 1.33915 & 1.33197 & 1.33183 & 1.33185 \\
\hline & & & & &
\end{tabular}


Table S4. Comparing the predicted bond lengths of F3TCNQ 1 to F4-TCNQ.

\begin{tabular}{ccccc}
\hline Bond & F4-TCNQ & \multicolumn{3}{c}{ F3-TCNQ 1 } \\
\hline $\mathrm{R}_{1}$ & $-\mathrm{F}$ & $-\mathrm{CH}_{2}-$ & & $\%$ \\
\hline $\mathrm{C}_{2}-\mathrm{R}_{1}$ & 1.33908 & 1.51586 & & \\
$\mathrm{C}_{1}-\mathrm{C}_{2}$ & 1.35908 & 1.36498 & -0.0059 & $-0.43 \%$ \\
$\mathrm{C}_{1}-\mathrm{C}_{6}$ & 1.44563 & 1.44684 & -0.00121 & $-0.08 \%$ \\
$\mathrm{C}_{2}-\mathrm{C}_{3}$ & 1.44563 & 1.46458 & -0.01895 & $-1.31 \%$ \\
$\mathrm{C}_{3}-\mathrm{C}_{8}$ & 1.38831 & 1.3932 & -0.00489 & $-0.35 \%$ \\
$\mathrm{C}_{8}-\mathrm{C}_{19}$ & 1.42921 & 1.4324 & -0.00319 & $-0.22 \%$ \\
$\mathrm{C}_{3}-\mathrm{C}_{4}$ & 1.44562 & 1.45103 & -0.00541 & $-0.37 \%$ \\
$\mathrm{C}_{4}-\mathrm{C}_{5}$ & 1.35909 & 1.35629 & 0.0028 & $0.21 \%$ \\
$\mathrm{C}_{5}-\mathrm{C}_{6}$ & 1.44562 & 1.43862 & 0.007 & $0.48 \%$ \\
$\mathrm{C}_{6}-\mathrm{C}_{7}$ & 1.38839 & 1.38859 & -0.0002 & $-0.01 \%$ \\
$\mathrm{C}_{7}-\mathrm{C}_{9}$ & 1.42926 & 1.42945 & -0.00019 & $-0.01 \%$ \\
$\mathrm{C}_{7}-\mathrm{C}_{11}$ & 1.42926 & 1.42988 & -0.00062 & $-0.04 \%$ \\
$\mathrm{C}_{9}-\mathrm{N}_{10}$ & 1.16424 & 1.16426 & $-2 \mathrm{E}-05$ & $0.00 \%$ \\
$\mathrm{C}_{11}-\mathrm{N}_{12}$ & 1.16424 & 1.16416 & $8 \mathrm{E}-05$ & $0.01 \%$ \\
$\mathrm{C}_{19}-\mathrm{N}_{20}$ & 1.16409 & 1.16443 & -0.00034 & $-0.03 \%$ \\
$\mathrm{C}_{13}-\mathrm{N}_{14}$ & 1.16409 & 1.16489 & -0.0008 & $-0.07 \%$ \\
$\mathrm{C}_{1}-\mathrm{F}_{18}$ & 1.33103 & 1.34213 & -0.0111 & $-0.83 \%$ \\
$\mathrm{C}_{4}-\mathrm{F}_{16}$ & 1.33096 & 1.33374 & -0.00278 & $-0.21 \%$ \\
$\mathrm{C}_{5}-\mathrm{F}_{15}$ & 1.33102 & 1.33915 & -0.00813 & $-0.61 \%$ \\
\hline & & & &
\end{tabular}

Table S5. Comparing the predicted bond lengths of F3TCNQ 2 to F4-TCNQ.

\begin{tabular}{ccccc}
\hline Bond & F4-TCNQ & \multicolumn{3}{c}{ F3-TCNQ 2 } \\
\hline $\mathrm{R}_{1}$ & $-\mathrm{F}$ & $-\mathrm{CH}_{2}-$ & & $\%$ \\
\hline $\mathrm{C}_{2}-\mathrm{R}_{1}$ & 1.33908 & 1.52103 & & \\
$\mathrm{C}_{1}-\mathrm{C}_{2}$ & 1.35908 & 1.36393 & -0.00485 & $-0.36 \%$ \\
$\mathrm{C}_{1}-\mathrm{C}_{6}$ & 1.44563 & 1.44869 & -0.00306 & $-0.21 \%$ \\
$\mathrm{C}_{2}-\mathrm{C}_{3}$ & 1.44563 & 1.46666 & -0.02103 & $-1.45 \%$ \\
$\mathrm{C}_{3}-\mathrm{C}_{8}$ & 1.38831 & 1.39273 & -0.00442 & $-0.32 \%$ \\
$\mathrm{C}_{8}-\mathrm{C}_{19}$ & 1.42921 & 1.43264 & -0.00343 & $-0.24 \%$ \\
$\mathrm{C}_{3}-\mathrm{C}_{4}$ & 1.44562 & 1.45065 & -0.00503 & $-0.35 \%$ \\
$\mathrm{C}_{4}-\mathrm{C}_{5}$ & 1.35909 & 1.3564 & 0.00269 & $0.20 \%$ \\
$\mathrm{C}_{5}-\mathrm{C}_{6}$ & 1.44562 & 1.43777 & 0.00785 & $0.54 \%$ \\
$\mathrm{C}_{6}-\mathrm{C}_{7}$ & 1.38839 & 1.38835 & $4 \mathrm{E}-05$ & $0.00 \%$ \\
$\mathrm{C}_{7}-\mathrm{C}_{9}$ & 1.42926 & 1.42955 & -0.00029 & $-0.02 \%$ \\
$\mathrm{C}_{7}-\mathrm{C}_{11}$ & 1.42926 & 1.43009 & -0.00083 & $-0.06 \%$ \\
$\mathrm{C}_{9}-\mathrm{N}_{10}$ & 1.16424 & 1.16424 & 0 & $0.00 \%$ \\
$\mathrm{C}_{11}-\mathrm{N}_{12}$ & 1.16424 & 1.16414 & $1 \mathrm{E}-04$ & $0.01 \%$ \\
$\mathrm{C}_{19}-\mathrm{N}_{20}$ & 1.16409 & 1.16441 & -0.00032 & $-0.03 \%$ \\
$\mathrm{C}_{13}-\mathrm{N}_{14}$ & 1.16409 & 1.16479 & -0.0007 & $-0.06 \%$ \\
$\mathrm{C}_{1}-\mathrm{F}_{18}$ & 1.33103 & 1.34357 & -0.01254 & $-0.94 \%$ \\
$\mathrm{C}_{4}-\mathrm{F}_{16}$ & 1.33096 & 1.33342 & -0.00246 & $-0.18 \%$ \\
$\mathrm{C}_{5}-\mathrm{F}_{15}$ & 1.33102 & 1.33197 & -0.00095 & $-0.07 \%$ \\
\hline & & & &
\end{tabular}

Table S6. Comparing the predicted bond lengths of F3TCNQ 3 to F4-TCNQ.

\begin{tabular}{ccccc}
\hline Bond & F4-TCNQ & \multicolumn{3}{c}{ F3-TCNQ 3 } \\
\hline $\mathrm{R}_{1}$ & $-\mathrm{F}$ & $-\mathrm{O}-$ & & $\%$ \\
\hline $\mathrm{C}_{2}-\mathrm{R}_{1}$ & 1.33908 & 1.3411 & & \\
$\mathrm{C}_{1}-\mathrm{C}_{2}$ & 1.35908 & 1.36851 & -0.00943 & $-0.69 \%$ \\
$\mathrm{C}_{1}-\mathrm{C}_{6}$ & 1.44563 & 1.44173 & 0.0039 & $0.27 \%$ \\
$\mathrm{C}_{2}-\mathrm{C}_{3}$ & 1.44563 & 1.46265 & -0.01702 & $-1.18 \%$ \\
$\mathrm{C}_{3}-\mathrm{C}_{8}$ & 1.38831 & 1.38758 & 0.00073 & $0.05 \%$ \\
$\mathrm{C}_{8}-\mathrm{C}_{19}$ & 1.42921 & 1.43061 & -0.0014 & $-0.10 \%$ \\
$\mathrm{C}_{3}-\mathrm{C}_{4}$ & 1.44562 & 1.4445 & 0.00112 & $0.08 \%$ \\
$\mathrm{C}_{4}-\mathrm{C}_{5}$ & 1.35909 & 1.35708 & 0.00201 & $0.15 \%$ \\
$\mathrm{C}_{5}-\mathrm{C}_{6}$ & 1.44562 & 1.44532 & 0.0003 & $0.02 \%$ \\
$\mathrm{C}_{6}-\mathrm{C}_{7}$ & 1.38839 & 1.39021 & -0.00182 & $-0.13 \%$ \\
$\mathrm{C}_{7}-\mathrm{C}_{9}$ & 1.42926 & 1.42932 & $-6 \mathrm{E}-05$ & $0.00 \%$ \\
$\mathrm{C}_{7}-\mathrm{C}_{11}$ & 1.42926 & 1.42919 & $7 \mathrm{E}-05$ & $0.00 \%$ \\
$\mathrm{C}_{9}-\mathrm{N}_{10}$ & 1.16424 & 1.16431 & $-7 \mathrm{E}-05$ & $-0.01 \%$ \\
$\mathrm{C}_{11}-\mathrm{N}_{12}$ & 1.16424 & 1.1643 & $-6 \mathrm{E}-05$ & $-0.01 \%$ \\
$\mathrm{C}_{19}-\mathrm{N}_{20}$ & 1.16409 & 1.16419 & $-1 \mathrm{E}-04$ & $-0.01 \%$ \\
$\mathrm{C}_{13}-\mathrm{N}_{14}$ & 1.16409 & 1.16485 & -0.00076 & $-0.07 \%$ \\
$\mathrm{C}_{1}-\mathrm{F}_{18}$ & 1.33103 & 1.34154 & -0.01051 & $-0.79 \%$ \\
$\mathrm{C}_{4}-\mathrm{F}_{16}$ & 1.33096 & 1.3332 & -0.00224 & $-0.17 \%$ \\
$\mathrm{C}_{5}-\mathrm{F}_{15}$ & 1.33102 & 1.33183 & -0.00081 & $-0.06 \%$ \\
\hline & & & &
\end{tabular}

Table S7. Comparing the predicted bond lengths of F3TCNQ 4 to F4-TCNQ.

\begin{tabular}{ccccc}
\hline Bond & F4-TCNQ & \multicolumn{3}{c}{ F3-TCNQ-4 } \\
\hline $\mathrm{R}_{1}$ & $-\mathrm{F}$ & $-\mathrm{O}-$ & & $\%$ \\
\hline $\mathrm{C}_{2}-\mathrm{R}_{1}$ & 1.33908 & 1.34772 & & \\
$\mathrm{C}_{1}-\mathrm{C}_{2}$ & 1.35908 & 1.36804 & -0.00896 & $-0.66 \%$ \\
$\mathrm{C}_{1}-\mathrm{C}_{6}$ & 1.44563 & 1.44163 & 0.004 & $0.28 \%$ \\
$\mathrm{C}_{2}-\mathrm{C}_{3}$ & 1.44563 & 1.45874 & -0.01311 & $-0.91 \%$ \\
$\mathrm{C}_{3}-\mathrm{C}_{8}$ & 1.38831 & 1.38816 & 0.00015 & $0.01 \%$ \\
$\mathrm{C}_{8}-\mathrm{C}_{19}$ & 1.42921 & 1.43093 & -0.00172 & $-0.12 \%$ \\
$\mathrm{C}_{3}-\mathrm{C}_{4}$ & 1.44562 & 1.44478 & 0.00084 & $0.06 \%$ \\
$\mathrm{C}_{4}-\mathrm{C}_{5}$ & 1.35909 & 1.35736 & 0.00173 & $0.13 \%$ \\
$\mathrm{C}_{5}-\mathrm{C}_{6}$ & 1.44562 & 1.44511 & 0.00051 & $0.04 \%$ \\
$\mathrm{C}_{6}-\mathrm{C}_{7}$ & 1.38839 & 1.39059 & -0.0022 & $-0.16 \%$ \\
$\mathrm{C}_{7}-\mathrm{C}_{9}$ & 1.42926 & 1.42912 & 0.00014 & $0.01 \%$ \\
$\mathrm{C}_{7}-\mathrm{C}_{11}$ & 1.42926 & 1.42908 & 0.00018 & $0.01 \%$ \\
$\mathrm{C}_{9}-\mathrm{N}_{10}$ & 1.16424 & 1.1644 & -0.00016 & $-0.01 \%$ \\
$\mathrm{C}_{11}-\mathrm{N}_{12}$ & 1.16424 & 1.16438 & -0.00014 & $-0.01 \%$ \\
$\mathrm{C}_{19}-\mathrm{N}_{20}$ & 1.16409 & 1.16411 & $-2 \mathrm{E}-05$ & $0.00 \%$ \\
$\mathrm{C}_{13}-\mathrm{N}_{14}$ & 1.16409 & 1.16466 & -0.00057 & $-0.05 \%$ \\
$\mathrm{C}_{1}-\mathrm{F}_{18}$ & 1.33103 & 1.33636 & -0.00533 & $-0.40 \%$ \\
$\mathrm{C}_{4}-\mathrm{F}_{16}$ & 1.33096 & 1.33238 & -0.00142 & $-0.11 \%$ \\
$\mathrm{C}_{5}-\mathrm{F}_{15}$ & 1.33102 & 1.33185 & -0.00083 & $-0.06 \%$ \\
\hline & & & &
\end{tabular}


Table S8. Comparing the predicted bond angles of F3TCNQ 1 to F4-TCNQ.

\begin{tabular}{|c|c|c|c|c|}
\hline \multirow{2}{*}{$\begin{array}{c}\text { angles } \\
\text { R1 }\end{array}$} & \multirow{2}{*}{$\frac{\text { F4-TCNQ }}{-\mathrm{F}}$} & \multicolumn{3}{|c|}{ F3-TCNQ 1} \\
\hline & & $-\mathrm{CH}_{2}-$ & & $\%$ \\
\hline $\mathrm{C}_{1}-\mathrm{C}_{2}-\mathrm{C}_{3}$ & 122.74 & 117.82 & 4.92 & $4.01 \%$ \\
\hline $\mathrm{C}_{2}-\mathrm{C}_{3}-\mathrm{C}_{4}$ & 114.53 & 116.15 & -1.62 & $-1.41 \%$ \\
\hline $\mathrm{C}_{3}-\mathrm{C}_{4}-\mathrm{C}_{5}$ & 122.74 & 123.48 & -0.74 & $-0.60 \%$ \\
\hline $\mathrm{C}_{4}-\mathrm{C}_{5}-\mathrm{C}_{6}$ & 122.74 & 121.97 & 0.77 & $0.63 \%$ \\
\hline $\mathrm{C}_{1}-\mathrm{C}_{6}-\mathrm{C}_{5}$ & 114.53 & 113.69 & 0.84 & $0.73 \%$ \\
\hline $\mathrm{C}_{2}-\mathrm{C}_{3}-\mathrm{C}_{8}$ & 122.73 & 125.13 & -2.4 & $-1.96 \%$ \\
\hline $\mathrm{C}_{4}-\mathrm{C}_{3}-\mathrm{C}_{8}$ & 122.74 & 118.72 & 4.02 & $3.28 \%$ \\
\hline $\mathrm{C}_{1}-\mathrm{C}_{6}-\mathrm{C}_{7}$ & 122.74 & 123.53 & -0.79 & $-0.64 \%$ \\
\hline $\mathrm{C}_{5}-\mathrm{C}_{6}-\mathrm{C}_{7}$ & 122.74 & 122.78 & -0.04 & $-0.03 \%$ \\
\hline $\mathrm{C}_{6}-\mathrm{C}_{7}-\mathrm{C}_{9}$ & 123.73 & 124.19 & -0.46 & $-0.37 \%$ \\
\hline $\mathrm{C}_{6}-\mathrm{C}_{7}-\mathrm{C}_{11}$ & 123.73 & 123.54 & 0.19 & $0.15 \%$ \\
\hline $\mathrm{C}_{9}-\mathrm{C}_{7}-\mathrm{C}_{11}$ & 112.55 & 112.27 & 0.28 & $0.25 \%$ \\
\hline $\mathrm{C}_{3}-\mathrm{C}_{8}-\mathrm{C}_{13}$ & 123.74 & 125.51 & -1.77 & $-1.43 \%$ \\
\hline $\mathrm{C}_{3}-\mathrm{C}_{8}-\mathrm{C}_{19}$ & 123.72 & 124.68 & -0.96 & $-0.78 \%$ \\
\hline $\mathrm{C}_{13}-\mathrm{C}_{8}-\mathrm{C}_{19}$ & 112.54 & 109.79 & 2.75 & $2.44 \%$ \\
\hline $\mathrm{R}_{1}-\mathrm{C}_{2}-\mathrm{C}_{3}$ & 118.83 & 125.42 & -6.59 & $-5.55 \%$ \\
\hline $\mathrm{R}_{1}-\mathrm{C}_{2}-\mathrm{C}_{1}$ & 118.43 & 116.76 & 1.67 & $1.41 \%$ \\
\hline $\mathrm{F}_{18}-\mathrm{C}_{1}-\mathrm{C}_{2}$ & 118.43 & 117.98 & 0.45 & $0.38 \%$ \\
\hline $\mathrm{F}_{18}-\mathrm{C}_{1}-\mathrm{C}_{6}$ & 118.83 & 115.22 & 3.61 & $3.04 \%$ \\
\hline $\mathrm{F}_{15}-\mathrm{C}_{5}-\mathrm{C}_{6}$ & 118.83 & 119.35 & -0.52 & $-0.44 \%$ \\
\hline $\mathrm{F}_{15}-\mathrm{C}_{5}-\mathrm{C}_{4}$ & 118.43 & 118.67 & -0.24 & $-0.20 \%$ \\
\hline $\mathrm{F}_{16}-\mathrm{C}_{4}-\mathrm{C}_{5}$ & 118.43 & 117.2 & 1.23 & $1.04 \%$ \\
\hline $\mathrm{F}_{16}-\mathrm{C}_{4}-\mathrm{C}_{3}$ & 118.83 & 119.31 & -0.48 & $-0.40 \%$ \\
\hline
\end{tabular}

Table S9. Comparing the predicted bond angles of F3TCNQ 2 to F4-TCNQ.

\begin{tabular}{|c|c|c|c|c|}
\hline angles & F4TCNQ & & F3-TCN & \\
\hline R1 & $-F$ & $-\mathrm{CH}_{2-}$ & & $\%$ \\
\hline $\mathrm{C}_{1}-\mathrm{C}_{2}-\mathrm{C}_{3}$ & 122.74 & 117.78 & 4.96 & $4.04 \%$ \\
\hline $\mathrm{C}_{2}-\mathrm{C}_{3}-\mathrm{C}_{4}$ & 114.53 & 116.1 & -1.57 & $-1.37 \%$ \\
\hline $\mathrm{C}_{3}-\mathrm{C}_{4}-\mathrm{C}_{5}$ & 122.74 & 123.43 & -0.69 & $-0.56 \%$ \\
\hline $\mathrm{C}_{4}-\mathrm{C}_{5}-\mathrm{C}_{6}$ & 122.74 & 121.96 & 0.78 & $0.64 \%$ \\
\hline $\mathrm{C}_{1}-\mathrm{C}_{6}-\mathrm{C}_{5}$ & 114.53 & 113.74 & 0.79 & $0.69 \%$ \\
\hline $\mathrm{C}_{2}-\mathrm{C}_{3}-\mathrm{C}_{8}$ & 122.73 & 125.32 & -2.59 & $-2.11 \%$ \\
\hline $\mathrm{C}_{4}-\mathrm{C}_{3}-\mathrm{C}_{8}$ & 122.74 & 118.56 & 4.18 & $3.41 \%$ \\
\hline $\mathrm{C}_{1}-\mathrm{C}_{6}-\mathrm{C}_{7}$ & 122.74 & 123.5 & -0.76 & $-0.62 \%$ \\
\hline $\mathrm{C}_{5}-\mathrm{C}_{6}-\mathrm{C}_{7}$ & 122.74 & 122.76 & -0.02 & $-0.02 \%$ \\
\hline $\mathrm{C}_{6}-\mathrm{C}_{7}-\mathrm{C}_{9}$ & 123.73 & 124.28 & -0.55 & $-0.44 \%$ \\
\hline $\mathrm{C}_{6}-\mathrm{C}_{7}-\mathrm{C}_{11}$ & 123.73 & 123.51 & 0.22 & $0.18 \%$ \\
\hline $\mathrm{C}_{9}-\mathrm{C}_{7}-\mathrm{C}_{11}$ & 112.55 & 112.21 & 0.34 & $0.30 \%$ \\
\hline $\mathrm{C}_{3}-\mathrm{C}_{8}-\mathrm{C}_{13}$ & 123.74 & 125.57 & -1.83 & $-1.48 \%$ \\
\hline $\mathrm{C}_{3}-\mathrm{C}_{8}-\mathrm{C}_{19}$ & 123.72 & 124.67 & -0.95 & $-0.77 \%$ \\
\hline $\mathrm{C}_{13}-\mathrm{C}_{8}-\mathrm{C}_{19}$ & 112.54 & 109.71 & 2.83 & $2.51 \%$ \\
\hline $\mathrm{R}_{1}-\mathrm{C}_{2}-\mathrm{C}_{3}$ & 118.83 & 124.65 & -5.82 & $-4.90 \%$ \\
\hline $\mathrm{R}_{1}-\mathrm{C}_{2}-\mathrm{C}_{1}$ & 118.43 & 117.43 & 1 & $0.84 \%$ \\
\hline $\mathrm{F}_{18}-\mathrm{C}_{1}-\mathrm{C}_{2}$ & 118.43 & 118.5 & -0.07 & $-0.06 \%$ \\
\hline $\mathrm{F}_{18}-\mathrm{C}_{1}-\mathrm{C}_{6}$ & 118.83 & 114.7 & 4.13 & $3.48 \%$ \\
\hline $\mathrm{F}_{15}-\mathrm{C}_{5}-\mathrm{C}_{6}$ & 118.83 & 119.37 & -0.54 & $-0.45 \%$ \\
\hline $\mathrm{F}_{15}-\mathrm{C}_{5}-\mathrm{C}_{4}$ & 118.43 & 118.66 & -0.23 & $-0.19 \%$ \\
\hline $\mathrm{F}_{16}-\mathrm{C}_{4}-\mathrm{C}_{5}$ & 118.43 & 117.16 & 1.27 & $1.07 \%$ \\
\hline $\mathrm{F}_{16}-\mathrm{C}_{4}-\mathrm{C}_{3}$ & 118.83 & 119.34 & -0.51 & $-0.43 \%$ \\
\hline
\end{tabular}

Table S10. Comparing the predicted bond angles of F3TCNQ 3 to F4-TCNQ.

\begin{tabular}{ccccc}
\hline angles & F4-TCNQ & \multicolumn{3}{c}{ F3-TCNQ 3 } \\
\hline $\mathrm{R} 1$ & $-\mathrm{F}$ & $-\mathrm{O}-$ & & $\%$ \\
\hline $\mathrm{C}_{1}-\mathrm{C}_{2}-\mathrm{C}_{3}$ & 122.74 & 119.59 & 3.15 & $2.57 \%$ \\
$\mathrm{C}_{2}-\mathrm{C}_{3}-\mathrm{C}_{4}$ & 114.53 & 116.09 & -1.56 & $-1.36 \%$ \\
$\mathrm{C}_{3}-\mathrm{C}_{4}-\mathrm{C}_{5}$ & 122.74 & 122.65 & 0.09 & $0.07 \%$ \\
$\mathrm{C}_{4}-\mathrm{C}_{5}-\mathrm{C}_{6}$ & 122.74 & 122.38 & 0.36 & $0.29 \%$ \\
$\mathrm{C}_{1}-\mathrm{C}_{6}-\mathrm{C}_{5}$ & 114.53 & 114.56 & -0.03 & $-0.03 \%$ \\
$\mathrm{C}_{2}-\mathrm{C}_{3}-\mathrm{C}_{8}$ & 122.73 & 122.12 & 0.61 & $0.50 \%$ \\
$\mathrm{C}_{4}-\mathrm{C}_{3}-\mathrm{C}_{8}$ & 122.74 & 121.77 & 0.97 & $0.79 \%$ \\
$\mathrm{C}_{1}-\mathrm{C}_{6}-\mathrm{C}_{7}$ & 122.74 & 123.09 & -0.35 & $-0.29 \%$ \\
$\mathrm{C}_{5}-\mathrm{C}_{6}-\mathrm{C}_{7}$ & 122.74 & 122.34 & 0.4 & $0.33 \%$ \\
$\mathrm{C}_{6}-\mathrm{C}_{7}-\mathrm{C}_{9}$ & 123.73 & 123.82 & -0.09 & $-0.07 \%$ \\
$\mathrm{C}_{6}-\mathrm{C}_{7}-\mathrm{C}_{11}$ & 123.73 & 123.81 & -0.08 & $-0.06 \%$ \\
$\mathrm{C}_{9}-\mathrm{C}_{7}-\mathrm{C}_{11}$ & 112.55 & 112.37 & 0.18 & $0.16 \%$ \\
$\mathrm{C}_{3}-\mathrm{C}_{8}-\mathrm{C}_{13}$ & 123.74 & 124.37 & -0.63 & $-0.51 \%$ \\
$\mathrm{C}_{3}-\mathrm{C}_{8}-\mathrm{C}_{19}$ & 123.72 & 123.96 & -0.24 & $-0.19 \%$ \\
$\mathrm{C}_{13}-\mathrm{C}_{8}-\mathrm{C}_{19}$ & 112.54 & 111.63 & 0.91 & $0.81 \%$ \\
$\mathrm{R}_{1}-\mathrm{C}_{2}-\mathrm{C}_{3}$ & 118.83 & 117.29 & 1.54 & $1.30 \%$ \\
$\mathrm{R}_{1}-\mathrm{C}_{2}-\mathrm{C}_{1}$ & 118.43 & 122.91 & -4.48 & $-3.78 \%$ \\
$\mathrm{~F}_{18}-\mathrm{C}_{1}-\mathrm{C}_{2}$ & 118.43 & 118.22 & 0.21 & $0.18 \%$ \\
$\mathrm{~F}_{18}-\mathrm{C}_{1}-\mathrm{C}_{6}$ & 118.83 & 117.18 & 1.65 & $1.39 \%$ \\
$\mathrm{~F}_{15}-\mathrm{C}_{5}-\mathrm{C}_{6}$ & 118.83 & 119.05 & -0.22 & $-0.19 \%$ \\
$\mathrm{~F}_{15}-\mathrm{C}_{5}-\mathrm{C}_{4}$ & 118.43 & 118.58 & -0.15 & $-0.13 \%$ \\
$\mathrm{~F}_{16}-\mathrm{C}_{4}-\mathrm{C}_{5}$ & 118.43 & 118.21 & 0.22 & $0.19 \%$ \\
$\mathrm{~F}_{16}-\mathrm{C}_{4}-\mathrm{C}_{3}$ & 118.83 & 119.12 & -0.29 & $-0.24 \%$ \\
\hline & & & &
\end{tabular}

Table S11. Comparing the predicted bond angles of F3TCNQ 4 to F4-TCNQ.

\begin{tabular}{ccccc}
\hline angles & F4-TCNQ & \multicolumn{3}{c}{ F3-TCNQ 4 } \\
\hline $\mathrm{R} 1$ & $-\mathrm{F}$ & $-\mathrm{O}-$ & & $\%$ \\
\hline $\mathrm{C}_{1}-\mathrm{C}_{2}-\mathrm{C}_{3}$ & 122.74 & 120.46 & 2.28 & $1.86 \%$ \\
$\mathrm{C}_{2}-\mathrm{C}_{3}-\mathrm{C}_{4}$ & 114.53 & 115.58 & -1.05 & $-0.92 \%$ \\
$\mathrm{C}_{3}-\mathrm{C}_{4}-\mathrm{C}_{5}$ & 122.74 & 122.77 & -0.03 & $-0.02 \%$ \\
$\mathrm{C}_{4}-\mathrm{C}_{5}-\mathrm{C}_{6}$ & 122.74 & 122.49 & 0.25 & $0.20 \%$ \\
$\mathrm{C}_{1}-\mathrm{C}_{6}-\mathrm{C}_{5}$ & 114.53 & 114.57 & -0.04 & $-0.03 \%$ \\
$\mathrm{C}_{2}-\mathrm{C}_{3}-\mathrm{C}_{8}$ & 122.73 & 122.53 & 0.2 & $0.16 \%$ \\
$\mathrm{C}_{4}-\mathrm{C}_{3}-\mathrm{C}_{8}$ & 122.74 & 121.89 & 0.85 & $0.69 \%$ \\
$\mathrm{C}_{1}-\mathrm{C}_{6}-\mathrm{C}_{7}$ & 122.74 & 123 & -0.26 & $-0.21 \%$ \\
$\mathrm{C}_{5}-\mathrm{C}_{6}-\mathrm{C}_{7}$ & 122.74 & 122.41 & 0.33 & $0.27 \%$ \\
$\mathrm{C}_{6}-\mathrm{C}_{7}-\mathrm{C}_{9}$ & 123.73 & 123.84 & -0.11 & $-0.09 \%$ \\
$\mathrm{C}_{6}-\mathrm{C}_{7}-\mathrm{C}_{11}$ & 123.73 & 123.76 & -0.03 & $-0.02 \%$ \\
$\mathrm{C}_{9}-\mathrm{C}_{7}-\mathrm{C}_{11}$ & 112.55 & 112.4 & 0.15 & $0.13 \%$ \\
$\mathrm{C}_{3}-\mathrm{C}_{8}-\mathrm{C}_{13}$ & 123.74 & 124.79 & -1.05 & $-0.85 \%$ \\
$\mathrm{C}_{3}-\mathrm{C}_{8}-\mathrm{C}_{19}$ & 123.72 & 123.7 & 0.02 & $0.02 \%$ \\
$\mathrm{C}_{13}-\mathrm{C}_{8}-\mathrm{C}_{19}$ & 112.54 & 111.52 & 1.02 & $0.91 \%$ \\
$\mathrm{R}_{1}-\mathrm{C}_{2}-\mathrm{C}_{3}$ & 118.83 & 116.27 & 2.56 & $2.15 \%$ \\
$\mathrm{R}_{1}-\mathrm{C}_{2}-\mathrm{C}_{1}$ & 118.43 & 123.02 & -4.59 & $-3.88 \%$ \\
$\mathrm{~F}_{18}-\mathrm{C}_{1}-\mathrm{C}_{2}$ & 118.43 & 118.32 & 0.11 & $0.09 \%$ \\
$\mathrm{~F}_{18}-\mathrm{C}_{1}-\mathrm{C}_{6}$ & 118.83 & 117.6 & 1.23 & $1.04 \%$ \\
$\mathrm{~F}_{15}-\mathrm{C}_{5}-\mathrm{C}_{6}$ & 118.83 & 119.01 & -0.18 & $-0.15 \%$ \\
$\mathrm{~F}_{15}-\mathrm{C}_{5}-\mathrm{C}_{4}$ & 118.43 & 118.49 & -0.06 & $-0.05 \%$ \\
$\mathrm{~F}_{16}-\mathrm{C}_{4}-\mathrm{C}_{5}$ & 118.43 & 118.17 & 0.26 & $0.22 \%$ \\
$\mathrm{~F}_{16}-\mathrm{C}_{4}-\mathrm{C}_{3}$ & 118.83 & 119.06 & -0.23 & $-0.19 \%$ \\
\hline & & & &
\end{tabular}


Table S12. Predicted dihedral angles for the substituted F3-TCNQ derivatives and that for F4-TCNQ.

\begin{tabular}{|c|c|c|c|c|c|}
\hline & F4-TCNQ & F3-TCNQ 1 & F3-TCNQ 2 & F3-TCNQ 3 & F3-TCNQ 4 \\
\hline $\mathrm{R} 1$ & $-\mathrm{F}$ & $-\mathrm{CH}_{2-}$ & $-\mathrm{CH}_{2-}$ & $-\mathrm{O}-$ & $-\mathrm{O}-$ \\
\hline $\mathrm{C}_{13}-\mathrm{C}_{8}-\mathrm{C}_{3}-\mathrm{C}_{2}$ & 0.00212 & 4.12008 & 6.67935 & 4.52283 & 0.79787 \\
\hline $\mathrm{C}_{19}-\mathrm{C}_{8}-\mathrm{C}_{3}-\mathrm{C}_{4}$ & 0.00098 & 2.78082 & 5.58563 & 3.21432 & 1.21882 \\
\hline $\mathrm{C}_{8}-\mathrm{C}_{3}-\mathrm{C}_{2}-\mathrm{R}_{1}$ & 0.0006 & 3.87512 & 11.2268 & 8.87781 & 5.42836 \\
\hline $\mathrm{R}_{1}-\mathrm{C}_{2}-\mathrm{C}_{1}-\mathrm{F}_{18}$ & 0.00014 & 0.8952 & 3.16005 & 3.6876 & 3.34499 \\
\hline $\mathrm{F}_{18}-\mathrm{C}_{1}-\mathrm{C}_{6}-\mathrm{C}_{7}$ & 0.00013 & 1.07238 & 3.81382 & 2.66947 & 1.62426 \\
\hline $\mathrm{C}_{1}-\mathrm{C}_{6}-\mathrm{C}_{7}-\mathrm{C}_{9}$ & 0.00194 & 0.83946 & 1.03493 & 2.67938 & 2.41686 \\
\hline $\mathrm{C}_{5}-\mathrm{C}_{6}-\mathrm{C}_{7}-\mathrm{C}_{11}$ & 0.00118 & 0.29082 & 0.18916 & 0.54908 & 0.14746 \\
\hline $\mathrm{C}_{7}-\mathrm{C}_{6}-\mathrm{C}_{5}-\mathrm{F}_{15}$ & 0.00043 & 0.26379 & 0.90043 & 0.17783 & 0.01668 \\
\hline $\mathrm{F}_{16}-\mathrm{C}_{4}-\mathrm{C}_{5}-\mathrm{F}_{15}$ & 0.00033 & 0.25238 & 0.43661 & 0.01227 & 0.4683 \\
\hline
\end{tabular}

